\title{
Life After Secretion - Yersinia enterocolitica Rapidly Toggles Effector Secretion and Can Resume Cell Division in Response to Changing External Conditions
}

\author{
Bailey Milne-Davies, Carlos Helbig, Stephan Wimmi, Dorothy W. C. Cheng ${ }^{\dagger}$, Nicole Paczia \\ and Andreas Diepold ${ }^{*}$
}

Department of Ecophysiology, Max Planck Institute for Terrestrial Microbiology, Marburg, Germany

OPEN ACCESS

Edited by:

Eric Cascales,

Aix-Marseille Université, France

Reviewed by:

Luís Jaime Mota,

New University of Lisbon, Portugal

Victoria Auerbuch,

University of California, Santa Cruz,

United States

*Correspondence:

Andreas Diepold

andreas.diepold@

mpi-marburg.mpg.de

${ }^{\dagger}$ Present address:

Dorothy W. C. Cheng

Department of Chemistry, Reed College, Portland, OR, United States

Specialty section:

This article was submitted to Microbial Physiology and Metabolism,

a section of the journa

Frontiers in Microbiology

Received: 04 March 2019

Accepted: 29 August 2019 Published: 13 September 2019

Citation:

Milne-Davies B, Helbig C, Wimmi S, Cheng DWC, Paczia N and Diepold A (2019) Life After Secretion-Yersinia enterocolitica Rapidly Toggles Effector

Secretion and Can Resume Cell Division in Response to Changing External Conditions.

Front. Microbiol. 10:2128 doi: 10.3389/fmicb.2019.02128
Many pathogenic bacteria use the type III secretion system (T3SS) injectisome to manipulate host cells by injecting virulence-promoting effector proteins into the host cytosol. The T3SS is activated upon host cell contact, and its activation is accompanied by an arrest of cell division; hence, many species maintain a T3SS-inactive sibling population to propagate efficiently within the host. The enteric pathogen Yersinia enterocolitica utilizes the T3SS to prevent phagocytosis and inhibit inflammatory responses. Unlike other species, almost all Y. enterocolitica are T3SS-positive at $37^{\circ} \mathrm{C}$, which raises the question, how these bacteria are able to propagate within the host, that is, when and how they stop secretion and restart cell division after a burst of secretion. Using a fast and quantitative in vitro secretion assay, we have examined the initiation and termination of type III secretion. We found that effector secretion begins immediately once the activating signal is present, and instantly stops when this signal is removed. Following effector secretion, the bacteria resume division within minutes after being introduced to a non-secreting environment, and the same bacteria are able to re-initiate effector secretion at later time points. Our results indicate that $Y$. enterocolitica use their type III secretion system to promote their individual survival when necessary, and are able to quickly switch their behavior toward replication afterwards, possibly gaining an advantage during infection.

Keywords: bacterial protein secretion, host-pathogen interaction, regulation of virulence mechanisms, protein translocation, Yersinia enterocolitica, enteropathogens

\section{INTRODUCTION}

Bacteria use their type III secretion systems (T3SS) in a variety of ways to survive in different environments. The virulence-associated $\mathrm{T} \mathrm{SS}^{1}$ is a membrane-spanning nanosyringe that is used by various Gram-negative bacteria to export effector proteins into the cytoplasm of eukaryotic host cells, allowing them to modify host cell behavior (Cornelis, 2006; Galán, 2009; Pha, 2016).

\footnotetext{
${ }^{1}$ In this manuscript, T3SS refers to virulence-associated T3SS. The common "Sct" nomenclature (Hueck, 1998; Portaliou et al., 2016) is used for T3SS components, see (Diepold and Wagner, 2014) for species-specific names.
} 
The T3SS protein complex, commonly named the injectisome, is comprised of an extracellular needle, a series of membrane rings embedding an export apparatus, and several cytosolic components (Figure 1A). The needle creates a continuous channel that connects the bacterium to the host cytoplasm with the help of translocator proteins that form a needle tip and a pore within the host cell membrane (Håkansson et al., 1996; Nauth et al., 2018; Park et al., 2018), thus allowing the translocation of effector proteins. The membrane rings anchor the injectisome in the peptidoglycan and the inner and outer membrane, while the export apparatus facilitates the transfer of effectors from the bacterial cytosol through the needle (Kuhlen et al., 2018). The cytosolic components, which shuttle between the cytosol and the injectisome, bind to chaperone-effector complexes and govern the order of secretion (Akeda and Galán, 2005; LaraTejero et al., 2011; Diepold et al., 2015). During the assembly and function of the T3SS, three substrate classes are subsequently exported. The early substrates include the needle subunit and a ruler protein that determines the length of the needle. Once the correct needle length is reached, the hydrophilic translocator, classified as intermediate substrate, is exported and assembles a needle tip (Mueller et al., 2005). At this stage, the T3SS is in a standby mode (Enninga and Rosenshine, 2009), and secretion of the late substrates, the pore-forming hydrophobic translocators and the virulence effectors, can be induced, for example by host cell contact.

Pathogens including Salmonella, Shigella, Pseudomonas, and Yersinia use their T3SS to promote survival and enhance pathogenicity within the host (Büttner, 2012; Deng et al., 2017). In some pathogenic species, such as Salmonella enterica and Pseudomonas aeruginosa, T3SS are heterogeneously expressed resulting in two subpopulations (Rietsch and Mekalanos, 2006; Sturm et al., 2011; Rundell et al., 2016). The resulting mixed populations can allow bacteria that express the T3SS to promote the survival of their siblings that do not. This is evident for the T3SS encoded by the Salmonella pathogenicity island (SPI)1, where bacteria utilize their T3SS to promote entry into host cells, but also to induce inflammation of the intestinal lumen and remove competition of the intestinal flora (Stecher et al., 2007; Müller et al., 2009; Knodler et al., 2010; Behnsen et al., 2014). The SPI-1-utilizing bacteria display a retarded growth rate, which is a common trait of actively type III-secreting bacteria (Kupferberg and Higuchi, 1958; Mehigh et al., 1989; Fowler and Brubaker, 1994; Sturm et al., 2011). As a result, bacteria that do not express their T3SS outgrow the SPI-1-active population, which can be interpreted as an investment of the SPI-1-active bacteria into increased chances for their genetically identical SPI-1-inactive siblings (Sturm et al., 2011; Diard et al., 2013; Sánchez-Romero and Casadesús, 2018; Weigel and Dersch, 2018).

Yersinia enterocolitica is considered a largely extracellular pathogen that uses its T3SS mainly to prevent phagocytosis, inhibit inflammatory responses and promote dissemination (Navarro et al., 2005; Cornelis, 2006; Galán, 2009; Pha, 2016). Once Yersinia are exposed to a temperature of $37^{\circ} \mathrm{C}$ (e.g., after entering a host organism), they start expressing T3SS components (Skurnik et al., 1984; Lambert de Rouvroit et al., 1992). During infection, Y. enterocolitica can come into contact with host cells, such as macrophages, dissociate, and possibly establish contact with further host cells. Contact with a host cell activates the secretion of effectors, called Yops (Yersinia outer proteins), by the T3SS (Cornelis, 2002). In vitro, this activation can be achieved by the chelation of calcium $\left(\mathrm{Ca}^{2+}\right)$ from the extracellular environment. Under these conditions, the bacteria begin exporting their effectors and upregulate effector expression (Cornelis et al., 1987; Wiley et al., 2007; Dewoody et al., 2013). In this study, we used strains based on wild-type Y. enterocolitica expressing all virulence effectors (MRS40), as well as on a strain lacking the six main virulence effectors YopH,O,P,E,M,T, as well as the aspartate-beta-semialdehyde dehydrogenase gene ( $\triangle$ HOPEMTasd), which is consequently avirulent, auxotrophic for the cell wall component diaminopimelic acid, and can be analyzed under safety class 1 conditions.

Prior studies have mainly focused on the activation of the T3SS by host cell contact or $\mathrm{Ca}^{2+}$ chelation. However, the postsecretion events like deactivation, reestablishment of bacterial division and the possibility of reactivation of the T3SS are likely to play an equally essential role in promoting bacterial survival and pathogenesis within the host. We therefore used a fast and quantitative in vitro secretion assay to examine the initiation and termination of type III secretion in Y. enterocolitica, monitored the rate of cell growth and division throughout these steps, and assessed whether previously T3SS-active bacteria can initiate further secretion events. Our results show that activation and deactivation occur immediately in response to changing external conditions, and that after secretion, bacteria transition back to division within short time, while remaining able to reactivate their T3SS.

\section{RESULTS}

\section{Expression and Assembly of the Y. enterocolitica T3SS Is Uniform and Stable Under Different Conditions}

Earlier visualizations of T3SS components within $Y$. enterocolitica showed that most bacteria express T3SS, which are localized in a non-random pattern of small patches visible as fluorescent foci at the bacterial surface (Diepold et al., 2010, 2017; Kudryashev et al., 2015). To quantify the fraction of T3SSpositive $Y$. enterocolitica, we analyzed how many bacteria within a population displayed this standard pattern of fluorescence for functional EGFP-labeled versions of a T3SS inner membrane ring protein ( $\mathrm{SctD}$ ), and a cytosolic protein (SctQ) at $37^{\circ} \mathrm{C}$. Both under non-secreting conditions (presence of $5 \mathrm{mM} \mathrm{Ca}{ }^{2+}$ in the medium) and secreting conditions (chelation of $\mathrm{Ca}^{2+}$ by addition of $5 \mathrm{mM}$ EGTA), all or almost all bacteria were T3SS-positive (Figure 1B, Supplementary Figure 1). Even after long-term incubation under secreting conditions for $3 \mathrm{~h}$, the vast majority of bacteria (>98\%) were T3SS-positive (Figure 1C).

\section{Activation Kinetics of the Y. enterocolitica T3SS by $\mathrm{Ca}^{2+}$ Chelation}

The previous results showed that $Y$. enterocolitica populations almost uniformly assemble T3SS injectisomes. We next analyzed 

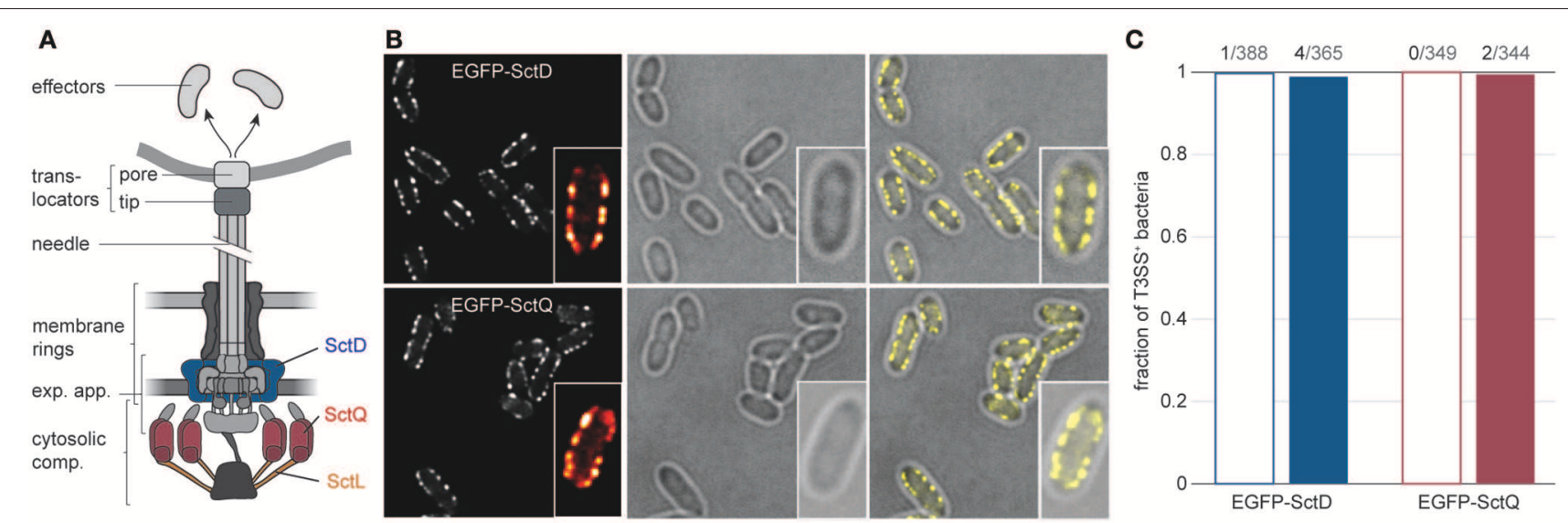

FIGURE 1 | The type III secretion system is expressed in almost all Y. enterocolitica, both under secreting and non-secreting conditions. (A) Schematic overview of the different substructures of the T3SS (left). Positions of the labeled proteins analyzed in this study are indicated (right). exp. app, export apparatus. (B) Micrographs of Y. enterocolitica $\triangle$ HOPEMTasd expressing EGFP-SctD (top) or EGFP-SctQ (bottom) from their native genetic localization. Three hours after induction of T3SS expression by temperature shift to $37^{\circ} \mathrm{C}$ under non-secreting conditions, bacteria were subjected to secreting conditions, and imaged. Left, EGFP fluorescence (insets show fluorescence intensity for one enlarged bacterium in ImageJ red-hot coloring scale); center, corresponding phase contrast images; right, overlay. Larger fields of view and images of bacteria under non-secreting conditions are shown in Supplementary Figure 1. (C) Fraction of bacteria with standard expression and distribution of T3SS (multiple membrane foci) for the indicated fusion protein, $3 \mathrm{~h}$ after induction of expression of the T3SS under non-secreting conditions (empty bars) or secreting conditions (filled bars) $n=344-388$. Numbers on top indicate the number of bacteria that do not display multiple visible T3SS, and the number of analyzed bacteria. Secreting and non-secreting conditions refer to incubation in medium with addition of $5 \mathrm{mM} \mathrm{EGTA} \mathrm{or} \mathrm{CaCl}_{2}$, respectively.

the activation and deactivation of these injectisomes in more detail, using an improved version of a previously published enzymatic export assay (Diepold et al., 2015), which measures the export of the reporter construct $\mathrm{YopH}_{1-17}-\beta$-lactamase (Charpentier and Oswald, 2004; Marketon et al., 2005). The updated protocol utilizes the pACYC184 plasmid instead of $\mathrm{pBAD}$, which removes background $\beta$-lactamase activity (Supplementary Figure 2A). The higher signal/noise ratio of the modified assay allowed us to reliably quantify secretion in intervals of down to $5 \mathrm{~min}$, and we confirmed that the enzymatic assay itself is not strongly influenced by the used concentration of $\mathrm{CaCl}_{2}$ or EGTA (Supplementary Figure 2B). We therefore were able to quantify the initiation of secretion in $Y$. enterocolitica $\triangle$ HOPEMTasd within the first $15 \mathrm{~min}$ after $\mathrm{Ca}^{2+}$ chelation. Within this time range, secretion is difficult to quantify even in an accumulative standard in vitro secretion assay (Figure 2A). For the reporter export assay, bacteria were grown at $37^{\circ} \mathrm{C}$ under non-secreting conditions, allowing for assembly, but not activation of T3SS. Secretion was then activated by resuspension in medium lacking $\mathrm{Ca}^{2+}$ and samples were taken every $5 \mathrm{~min}$, and tested for export of the reporter substrate into the supernatant within the following $5 \mathrm{~min}$. The results of the reporter assay clearly show that secretion is fully active at the earliest time range after activation ( $0-5 \mathrm{~min}$ ) (Figure $2 \mathbf{B}$ ), suggesting that effector secretion is initiated immediately by $\mathrm{Ca}^{2+}$ chelation. To test whether this fast activation of effector secretion impacts the cellular ATP levels, we determined the adenylate energy charge $(([\mathrm{ATP}]+0.5[\mathrm{ADP}]) /([\mathrm{ATP}]+[\mathrm{ADP}]+[\mathrm{AMP}]))$ of wildtype $Y$. enterocolitica $\triangle$ HOPEMTasd, incubated under the same conditions, $10 \mathrm{~min}$ after activation of the T3SS. We found that the energy charge of the secreting cultures was not significantly decreased in this time range (Supplementary Figure 3). In line with these findings, the level of secretion of the reporter substrate remained constant throughout the first $2 \mathrm{~h}$ after secretion (Figure 2B, Supplementary Figure 4 and data not shown). Secretion activity in a freshly activated wild-type strain was comparable to that of a SctW (YopN) deletion strain, which is calcium-blind and continuously secretes effectors (Supplementary Figure 4), underlining that the level of protein secretion immediately after activation is comparable to the level during ongoing secretion.

\section{T3SS Effector Secretion Ceases Within Minutes After Removal of the Activating Signal}

Next, we measured if and how fast the T3SS is inactivated upon reintroduction of $\mathrm{Ca}^{2+}$ into the medium. Wild-type $Y$. enterocolitica that had been secreting for $2 \mathrm{~h}$ were subjected to non-secreting medium, and the export of the reporter substrate was measured in 10-min intervals afterwards. Already within the first period after $\mathrm{Ca}^{2+}$ addition, the export of the reporter strongly dropped compared to the control that was left under secreting conditions (Figure 3A, Supplementary Figure 4). Based on the amount of exported reporter substrate under non-secreting conditions over time (green bars in Figure 3A), deactivation is likely to occur within the first minutes after the removal of the activating signal. Similar to the activation, deactivation of secretion did not increase the energy charge of the bacteria within these time ranges (Supplementary Figure 3).

To further investigate the inactivation of secretion, we aimed to determine, which factor, temperature or $\mathrm{Ca}^{2+}$ concentration, has a greater effect on the export of different substrate classes. 


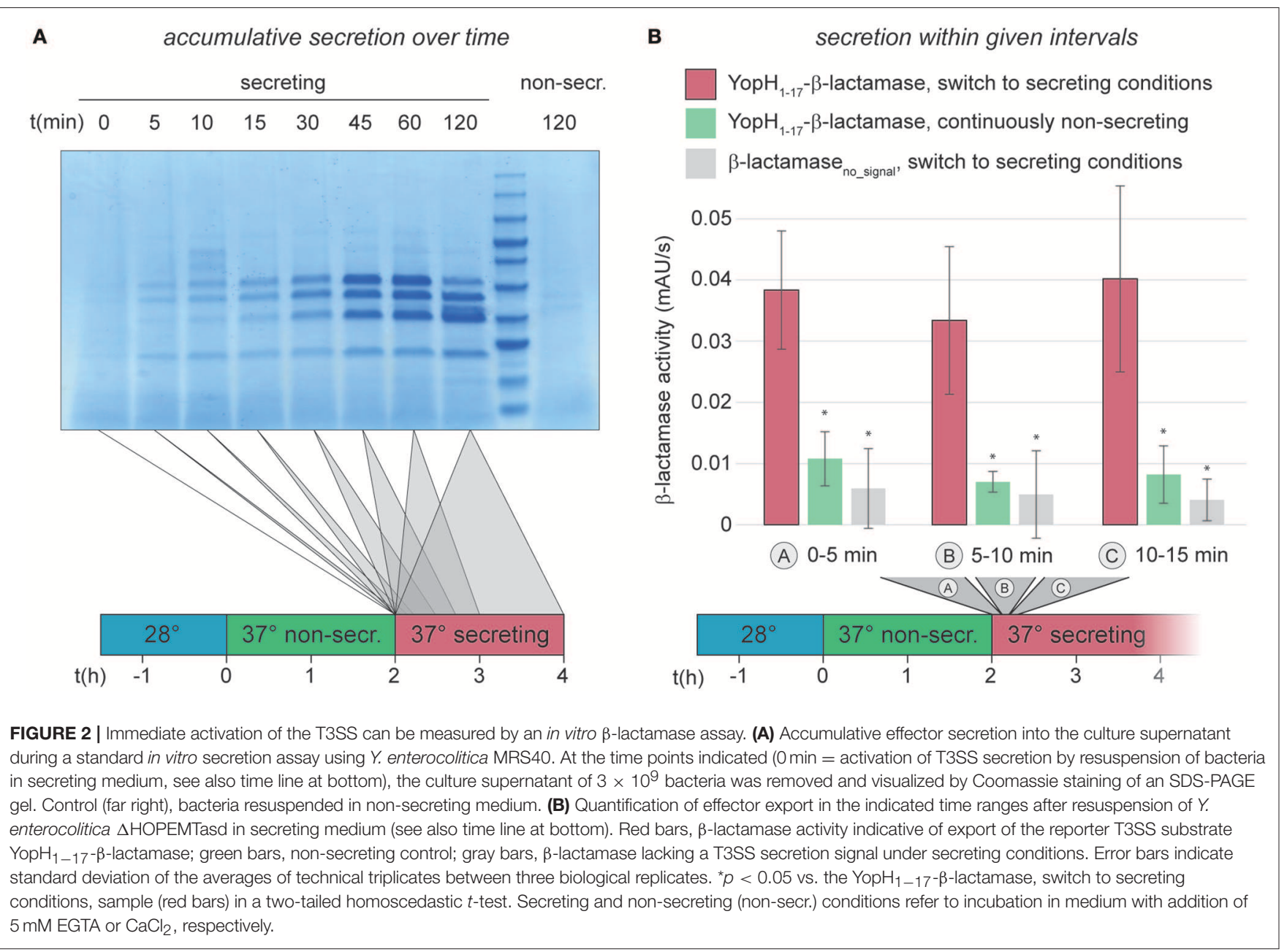

We therefore analyzed the export of virulence effectors (YopE and YopM), the needle protein SctF, the hydrophilic translocator SctA $(=\mathrm{LcrV})$, and the ruler protein SctP in a wild-type strain expressing all virulence effectors (MRS40). Cultures were grown in secreting conditions and after $3 \mathrm{~h}$, the previously secreting cultures were exposed to non-secreting or secreting conditions, at 26 or $37^{\circ} \mathrm{C}$. Our results show that while export of the virulence effectors was strongly repressed by the addition of $\mathrm{Ca}^{2+}$, they were secreted in the absence of $\mathrm{Ca}^{2+}$, irrespective of the temperature (Figures 3B,C). Export of the needle, translocator and ruler protein, in contrast, was more strongly influenced by the temperature than by the $\mathrm{Ca}^{2+}$ level, although this effect was not statistically significant for SctF and SctP (Figures 3B,C). The resuspension steps used in our protocol do not affect assembled needles, and in all cases, cell lysis was negligible; differences in expression levels cannot explain the observed export phenotype (Supplementary Figures 5-7).

\section{Y. enterocolitica Can Resume Growth or Engage in New Secretion Activity After Secretion Has Ended}

Having analyzed the activation and deactivation of type III secretion by external signals, we turned our interest to the events after secretion. Specifically, we wanted to find out whether and when post-secretion $Y$. enterocolitica can resume division and/or re-initiate secretion. To answer the first question, we compared the optical culture density of wild-type $Y$. enterocolitica (MRS40) bacteria that had previously been secreting, and were then either kept under secreting conditions, or subjected to nonsecreting conditions. Compared to the non-secreting control, secreting bacteria slow down their division (Figures 4A,B, "first incubation"). Strikingly, previously secreting bacteria that were subjected to non-secreting conditions resumed division within a short time (Figures 4A,B, "second incubation"). This phenotype is linked to T3SS activity, as indicated by the steady division of T3SS-negative $\Delta$ SctD bacteria under all tested conditions (Figures 4A,B). As expected, constantly secreting bacteria (the " $\mathrm{Ca}^{2+}$ blind" $\Delta \mathrm{SctW}(\Delta \mathrm{YopN})$ strain (Yother and Goguen, 1985), Supplementary Figure 7) displayed growth curves similar to wild-type under secreting conditions, irrespective of the medium. Similar results were obtained on solid medium, where T3SS-positive bacteria did not divide, and only slightly increased their cell volume, under sustained secreting conditions, in contrast to T3SS-negative bacteria (Figure 4C, Supplementary Figure 8). Under non-secreting conditions, both populations displayed a higher rate of growth and division 


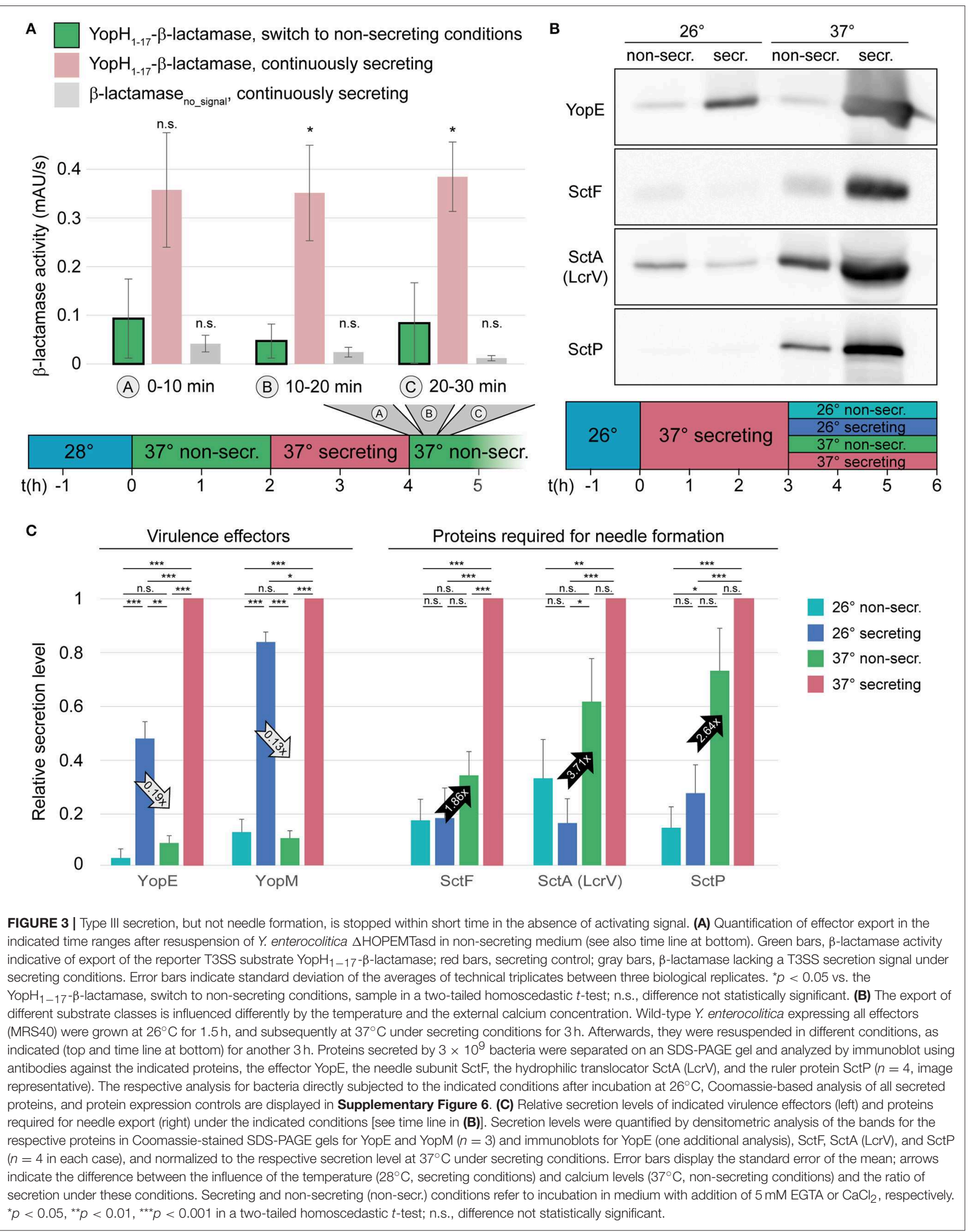




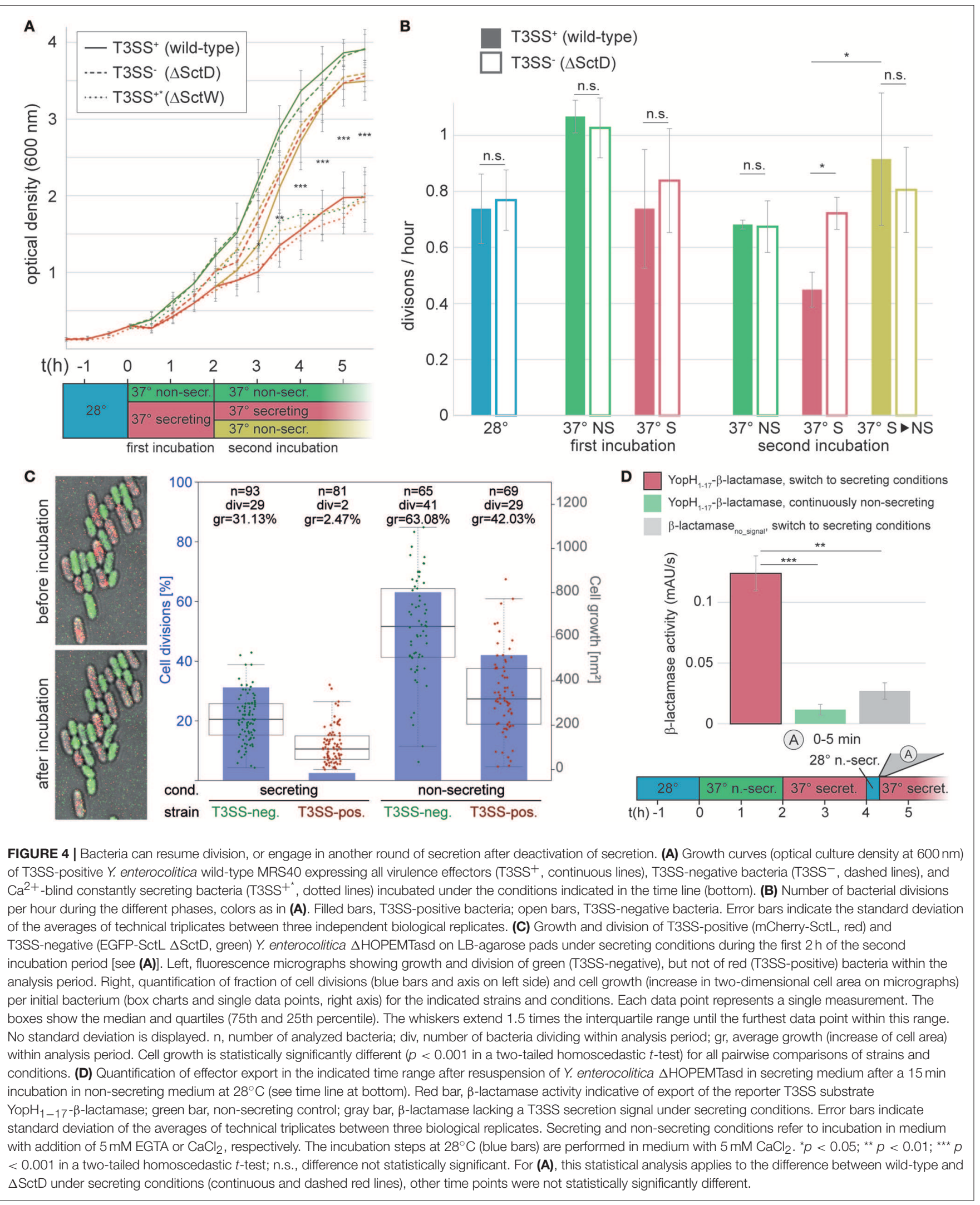


(Figure 4C, Supplementary Figure 8). Taken together, these results indicate that individual $Y$. enterocolitica cells not only can disengage from secretion within a short time, but also quickly resume division in the absence of further stimulating signals.

To determine if $Y$. enterocolitica can also go through repeated cycles of secretion activation and deactivation, we tested the reactivation of secretion in bacteria that had been secreting for $2 \mathrm{~h}$, and where secretion was stopped afterwards by addition of $\mathrm{CaCl}_{2}$. These bacteria were incubated in the presence of $\mathrm{Ca}^{2+}$ for $15 \mathrm{~min}$ at $28^{\circ} \mathrm{C}$ to suppress the formation of new injectisomes (Figure 3B), and then again subjected to secreting conditions $\left(37^{\circ} \mathrm{C}\right.$, absence of $\left.\mathrm{Ca}^{2+}\right)$. The secretion of effectors started within the first $5 \mathrm{~min}$ after the renewed incubation under secreting conditions (Figure 4D), which shows that type III secretion can be reactivated, and that this occurs within a similarly short time as the initial activation of secretion.

\section{DISCUSSION}

Life after secretion-the deactivation of the T3SS, the recovery of division, and possible additional encounters with host cellsis incompletely understood in Yersinia, despite the critical role of these events in the infection process. In this study, we therefore explored the kinetics of activation and, most crucially, deactivation of secretion by external cues, as well as the potential of $Y$. enterocolitica to restart division and to re-initiate secretion afterwards. During infection, when $Y$. enterocolitica enter the Peyer's Patches, bacteria may come into contact with immune cells. In this situation, fast initiation of effector export provides essential defense against phagocytosis and inflammatory signals to the immune system (Grosdent et al., 2002; Navarro et al., 2005; Galán, 2009; Pha, 2016; Philip et al., 2016). Such fast activation of type III secretion has indeed been shown for various bacteria (Enninga et al., 2005; Schlumberger et al., 2005; Mills et al., 2008). Following the interaction with the host, however, $Y$. enterocolitica conceivably benefit from stopping effector export, which may allow them to resume division and disseminate within the host (where the bacteria may again face contact with immune cells). To study T3SS activation and deactivation kinetics in a fast, reproducible and quantitative manner, we used an in vitro secretion assay for the reporter substrate $\beta$-lactamase in $Y$. enterocolitica, fused to the minimal secretion signal for the native Y. enterocolitica virulence effector YopH (Sory et al., 1995). Low and high calcium levels, as used in the assay, have been proposed to mimic the intracellular environment within host cells (low $\mathrm{Ca}^{2+}$ ), and the extracellular host environment (high $\mathrm{Ca}^{2+}$ ), respectively (Fowler and Brubaker, 1994). Our results show that just like activation of secretion (Figure 2), deactivation (Figure 3A) occurs immediately when introduced into secreting or non-secreting media, respectively.

The ability of $Y$. enterocolitica to respond quickly to these external stimuli suggests one or several highly sensitive regulation mechanisms. How exactly host cell contact and changes in the environment, such as the $\mathrm{Ca}^{2+}$ levels, are sensed, is still unclear. A number of studies, predominantly performed in Shigella flexneri and Pseudomonas aeruginosa, suggest that the needle tip senses host cell contact (Veenendaal et al., 2007; Roehrich et al., 2013; Armentrout and Rietsch, 2016), and that the signal is transmitted through rearrangements of the needle subunits to the cytosolic interface of the T3SS (Kenjale et al., 2005; Torruellas et al., 2005; Davis and Mecsas, 2006). Other external factors, such as the $\mathrm{Ca}^{2+}$ level and factors inducing other T3SS such as Congo Red might also be sensed at the needle tip and be transmitted the same way. However, the composition of the cytosolic complex of the Y. enterocolitica T3SS was shown to be influenced by external $\mathrm{Ca}^{2+}$ levels in strains lacking SctD (and therefore also not assembling needles), suggesting a direct sensing mechanism (Diepold et al., 2017). The $\mathrm{Ca}^{2+}$-dependent interaction of the ruler SctP and the cytosolic gatekeeper protein SctW in enteropathogenic E. coli (EPEC) supports yet another model in which the export of effectors is inhibited as long as a local influx of $\mathrm{Ca}^{2+}$ ions occurs through T3SS needles which are not in contact to a host cell (Shaulov et al., 2017).

Notably, in our deactivation experiments, not all substrate classes were affected equally by the $\mathrm{Ca}^{2+}$ level. While export of the tested effectors (YopE and YopM) was strongly suppressed upon addition of $\mathrm{Ca}^{2+}$, the export of early and intermediary substrates, required for the formation of new needles, continued, albeit at a lower rate. In contrast, a reduction of the temperature to $26^{\circ} \mathrm{C}$ at continuous low $\mathrm{Ca}^{2+}$ levels strongly decreased the export of early and intermediary substrates, but allowed the continued export of the effectors (Figure 3B). This phenotype is most likely not a mere effect of the expression levels of the exported proteins: While the initial expression of all T3SS export substrates is strongly regulated by the temperature, as a consequence of the temperature-dependent expression of the main transcriptional regulator of the T3SS, VirF (Cornelis et al., 1989; Hoe and Goguen, 1993; Böhme et al., 2012), this effect is far less pronounced in a system that has previously been activated by incubation at $37^{\circ} \mathrm{C}$ under secreting conditions (Supplementary Figures 6A,B). This indicates that in the latter case, mRNA and proteins levels are sufficient for continuous effector secretion at low $\mathrm{Ca}^{2+}$ levels, even at $26^{\circ} \mathrm{C}$. The secretion of the proteins required for needle formation is more strongly repressed at $26^{\circ} \mathrm{C}$ (although this effect is only statistically significant for $\mathrm{Sct} A=\mathrm{LcrV}$ ), suggesting that the inhibition of the secretion of needle-related proteins and effectors are controlled by additional, and different, regulatory pathways. A similar differential regulation of secretion of the different substrate classes has been shown for $P$. aeruginosa (Cisz et al., 2008) and EPEC (Shaulov et al., 2017), suggesting that this mechanism is conserved amongst different T3SS.

Regulating the events after secretion is particularly important for $Y$. enterocolitica, which differ from other pathogens in that they homogeneously express the T3SS when exposed to $37^{\circ} \mathrm{C}$ (Figure 1, Supplementary Figure 1), and that the complete population can activate secretion in vitro (Wiley et al., 2007). The low fraction of T3SS-negative bacteria even after prolonged in vitro secretion (Figure 1C), despite the lower replication rate of these bacteria, highlights the important role of T3SS function during infection in Y. enterocolitica. What then happens after a bacterium has survived an encounter with an immune cell? Once effector secretion has ceased, $Y$. 
enterocolitica benefit from re-initiating faster replication, but have to remain guarded for additional interactions with immune cells. It has been an open question whether re-initiation of replication can be observed in vitro, where all injectisomes are activated (Wiley et al., 2007), which might differ from the situation during an infection (Heroven and Dersch, 2014; Avican et al., 2015). We found that Y. enterocolitica can quickly resume division when exposed to a non-secreting environment after prior incubation in a secretion-activating environment (Figures 4A-C). This recovery (as well as the cessation of growth and division upon secretion initiation) appears independent of the cellular energy levels, which did not significantly drop under secreting conditions within the tested time range in the used effector-less strain (Supplementary Figure 3). At this point, renewed contact with host cells, especially immune cells, is possible. We have shown that accordingly, previously secreting $Y$. enterocolitica continue to assemble new needles (Figure 3B), and that reactivation of the T3SS is possible and occurs immediately when introduced from non-secreting media back into secreting media (Figure 4D). Reestablishing secretion likely allows the bacteria to defend themselves during future interactions with immune cells. Notably, the experiments to investigate the kinetics of secretion start and stop, as well as the re-initiation of growth and division, were performed in an effector-less strain background ( $\triangle$ HOPEMTasd). The observed effects are therefore independent of any additional regulatory role of the effectors themselves (Dewoody et al., 2013).

Effector translocation into macrophages prevents phagocytosis and inflammation, which both the interacting bacterium and bystanders benefit from. However, the ability to quickly restart growth after interaction with immune cells implies that $Y$. enterocolitica do not sacrifice to combat immune cells in an altogether altruistic manner, but also attempt to increase individual fitness. Other pathogens deviate from this strategy, and utilize their T3SS differently. In the wellstudied example of Salmonella Typhimurium SPI-1, only a fraction of bacteria express the T3SS, while the remaining bacteria do not express the T3SS. The SPI-1 activity elicits an inflammatory response that reduces competition with established microflora. Due to the inflammation and the decreased growth rate of the population expressing the SPI-1 T3SS genes, the subpopulation not expressing the SPI-1 genes outgrows both the SPI-1-expressing population and competing bacteria (Sturm et al., 2011; Diard et al., 2013; Weigel and Dersch, 2018). The cooperative virulence of Salmonella therefore allows for SPI-1 negative bacteria to colonize the intestinal lumen and thus promotes the competitiveness of the population and efficient invasion of the host (Stecher et al., 2007; Müller et al., 2009; Knodler et al., 2010; Ramos-Morales, 2012; Behnsen et al., 2014).

It is currently unclear whether the suppression of growth during secretion is based on the leakage of ions and amino acids, which might be either co-transported with the secreted proteins or passively diffuse through the T3SS during secretion (Fowler and Brubaker, 1994; Fowler et al., 2009), the metabolic burden caused by biosynthesis, assembly and operation of the T3SS (Brubaker, 2005; Sturm et al., 2011; Wilharm and Heider, 2014; Wang et al., 2016), yet unknown specific regulatory mechanisms, or a combination thereof. Wang et al. showed that in the related $Y$. pseudotuberculosis, activation of the T3SS by $\mathrm{Ca}^{2+}$ chelation or host cell contact leads to an increased copy number of the virulence plasmid (Wang et al., 2016). A decrease in virulence plasmid copy number upon deactivation of secretion could therefore increase the amount of energy available for growth and division; however, it is unclear whether such an effect could account for the rather quick recovery of growth and division presented in this study (Figures 4A,C). Notably, on solid medium, cell growth differs between secreting and non-secreting conditions (addition of $5 \mathrm{mM}$ EGTA or $\mathrm{CaCl}_{2}$, respectively) even for a T3SS-deficient strain (Figure 4C), which indicates an additional T3SS-independent effect of calcium or other divalent cations on growth on solid medium. Taken together, the finding that growth and cell division are restored within short time after secretion has ceased is most compatible with a direct effect of ion leakage, or a specific regulatory mechanism.

The results of this study describe important parameters of $Y$. enterocolitica's life after secretion. They show the ability to stop type III secretion and re-initiate growth and division within short time after the loss of the activating signal, while remaining able to enter another round of secretion, and support the notion that $Y$. enterocolitica applies the T3SS in an individual rather than a purely altruistic manner.

\section{MATERIALS AND METHODS}

Bacterial strains and constructs used in this study are listed in Table 1.

E. coli Top10 was used for cloning and grown on Luria-Bertani (LB) agar plates or in $\mathrm{LB}$ medium at $37^{\circ} \mathrm{C}$. Chloramphenicol and streptomycin were used to select for expression and suicide vectors at concentrations of 10 and $50 \mu \mathrm{g} / \mathrm{ml}$, respectively.

Yersinia enterocolitica strains were grown over night at $28^{\circ} \mathrm{C}$ in brain heart infusion (BHI) medium containing nalidixic acid $(35 \mu \mathrm{g} / \mathrm{ml})$, and diaminopimelic acid $(60 \mu \mathrm{g} / \mathrm{ml})$ for $\triangle$ HOPEMTasd strains. Day cultures were grown in BHI supplemented with nalidixic acid, diaminopimelic acid where required, $\mathrm{MgCl}_{2}(20 \mathrm{mM})$, and glycerol $(0.4 \% \mathrm{v} / \mathrm{v})$. For nonsecreting conditions, $5 \mathrm{mM} \mathrm{CaCl} 2$ was added to the medium, whereas for secreting conditions, residual $\mathrm{Ca}^{2+}$ was chelated by addition of 5 mM EGTA.

Plasmids were constructed using Phusion polymerase (New England Biolabs). Mutators for exchange of genes on the pYV virulence plasmid were created as previously described (Diepold et al., 2011). Inserted sequences were confirmed by sequencing (Eurofin Genomics). Y. enterocolitica mutants were generated by allelic exchange, resulting in the exchange of wild-type gene sequences with the mutated gene (Kaniga et al., 1991).

\section{$\beta$-Lactamase Assay}

$\triangle$ HOPEMTasd-based $Y$. enterocolitica were used for the $\beta$ lactamase (bla) assays to allow handling in a biological safety level 1 environment. $Y$. enterocolitica harboring pAD626

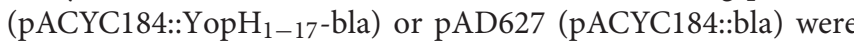
inoculated from overnight cultures to an optical density at $600 \mathrm{~nm}\left(\mathrm{OD}_{600}\right)$ of 0.10 (0.12 in validation experiment) in 
TABLE 1 | Bacterial strains and genetic constructs used in this study.

\begin{tabular}{|c|c|c|}
\hline Strain & Relevant characteristics of virulence plasmid & References \\
\hline \multicolumn{3}{|l|}{ Y. enterocolitica strains } \\
\hline MRS40 & Wild-type pYV plasmid of Y. enterocolitica E40 (pYve40) $\Delta$ blaA & Sory et al., 1995 \\
\hline IML421asd ( $\Delta$ HOPEMTasd) & 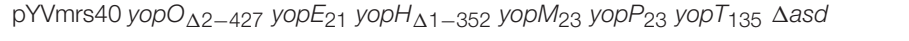 & Kudryashev et al., 2013 \\
\hline AD4051 & pYVmrs40 $\Delta s c t D$ & Diepold et al., 2010 \\
\hline AD4085 & pYViml421asd egfp-sctQ & Kudryashev et al., 2013 \\
\hline AD4306 & pYViml421asd egfp-sctD & Diepold et al., 2015 \\
\hline AD4483 & pYViml421asd egfp-sctL $\Delta s c t D$ & Diepold et al., 2017 \\
\hline ADTM4521 & pYViml421asd mCherry-sctL & This study \\
\hline IM41 & pYVmrs40 sctW 45 (does not encode sctW=yopN) & Boland et al., 1996 \\
\hline $\mathrm{CH} 4006$ & pYViml421asd sctF ${ }_{S 5 C}$ & This study \\
\hline Plasmid & Relevant characteristics & References \\
\hline \multicolumn{3}{|l|}{ Plasmids } \\
\hline pACYC184 & Expression vector & New England Biolabs \\
\hline pKNG101 & oriR6K sacBR ${ }^{+}$oriTRK2 strAB ${ }^{+}$(suicide vector) & Kaniga et al., 1991 \\
\hline pAD626 & $\begin{array}{l}\text { pACYC184::yopH } H_{1-17} \text {-bla }(\beta \text {-lactamase from pBAD::His-B cloned in-frame with first } \\
17 \text { amino acids of } Y \text {. enterocolitica yopH) }\end{array}$ & This study \\
\hline pAD627 & pACYC184::bla & This study \\
\hline pADTM521 & $\begin{array}{l}\text { pKNG101 mCh-sctL (pamCherry and flexible linker cloned in-frame at the N-terminus } \\
\text { of sctL) }\end{array}$ & Diepold et al., 2017 \\
\hline $\mathrm{pCHO6}$ & pKNG101 sctF $F_{S 5 C}$ (serine to cysteine point mutation of amino acid 5 in sctF) & This study \\
\hline
\end{tabular}

Strains and constructs used in this study. Y. enterocolitica strains are based on either the wild-type strain MRS40 or the multi-effector knock-out strain $\triangle$ HOPEMTasd (IML421asd),

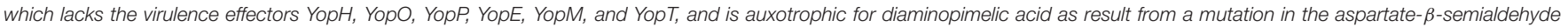
(asd) gene. The knock-out of the virulence effectors and the asd mutation is used for biosafety purposes, allowing these strains to be handled in a biosafety 1 level environment.

non-secreting BHI medium. After shaking incubation at $28^{\circ} \mathrm{C}$ for $1.5 \mathrm{~h}$, the culture was shifted to $37^{\circ} \mathrm{C}$ to induce the $y o p$ regulon. After $2 \mathrm{~h}(1.5 \mathrm{~h}$ in the initial validation experiment) of incubation at $37^{\circ} \mathrm{C}$, bacteria were collected (unless stated differently, bacteria were collected by centrifugation $(2,400 \mathrm{~g}$, $4 \mathrm{~min}, 37^{\circ} \mathrm{C}$ ), and resuspended in an equal amount of fresh medium pre-warmed to $37^{\circ} \mathrm{C}$ throughout the protocol), and resuspended in secreting $\mathrm{BHI}$ medium. Over the next $15 \mathrm{~min}$, the activation kinetics analysis was performed (see below). To determine the deactivation kinetics, cultures were incubated for $2 \mathrm{~h}$ at $37^{\circ} \mathrm{C}$ in secreting medium and were then collected and resuspended in non-secreting medium. Over the next $30 \mathrm{~min}$, the deactivation kinetics analysis was performed (see below). To determine the reactivation kinetics, cultures were incubated in the secreting medium for $2 \mathrm{~h}$ at $37^{\circ} \mathrm{C}$ and were then collected and resuspended in non-secreting medium pre-warmed to $28^{\circ} \mathrm{C}$. Cultures were incubated at $28^{\circ} \mathrm{C}$ for $15 \mathrm{~min}$, collected and resuspended in secreting medium at $37^{\circ} \mathrm{C}$, where the reactivation kinetics analysis was performed.

Samples for the kinetics analysis of activation, deactivation, and reactivation of secretion were treated as follows: after resuspension, 400-800 $\mu \mathrm{l}$ samples were removed from the culture at the indicated time points $(0,5,10 \mathrm{~min}$ for activation; $0,10,20 \mathrm{~min}$ for deactivation; $0 \mathrm{~min}$ for reactivation), collected, resuspended in fresh medium as indicated and incubated in a table top shaking incubator at $37^{\circ} \mathrm{C}, 800 \mathrm{rpm}$ for $5 \mathrm{~min}$ (activation and reactivation) or $10 \mathrm{~min}$ (deactivation). After this incubation, bacteria were removed by centrifugation $(16,000 \mathrm{~g}$, $2 \mathrm{~min}$ ), and the supernatant was stored at room temperature until all samples of one experiment were collected. For each sample, $100 \mu \mathrm{l}$ supernatant were added to a Sarstedt TC-Platte 96 well plate in triplicates. $10 \mu \mathrm{l} /$ well of $\beta$-lactamase substrate solution (10 $\mu \mathrm{M}$ Nitrocefin (Merck) in phosphate buffered saline) were added. $\beta$-lactamase activity was quantified by the increase in absorbance at $483 \mathrm{~nm}$, caused by $\beta$-lactamase catalyzed hydrolysis of Nitrocefin, for 40 rounds of $30 \mathrm{~s}$ each at $30^{\circ} \mathrm{C}$ using a Tecan Infinite 200 Pro photometer. The results are averages of $\beta$-lactamase activity, determined by linear regression within the linear range of the absorbance, of three independent experiments that were run in technical triplicates for each experiment.

The initial validation assay was performed as described above with the following modifications: $200 \mu \mathrm{l}$ supernatant was added to a Sarstedt TC-Platte 96 well plate in triplicates, and 20 $\mu \mathrm{l} /$ well of $\beta$-lactamase substrate solution $(20 \mu \mathrm{M}$ Fluorocillin Green 495/525 (Life Technologies in 0.1 M Tris-HCl pH 7.5) was added. $\beta$-lactamase activity was quantified by the increase in fluorescence caused by $\beta$-lactamase catalyzed hydrolysis of the substrate, measured at $495 \pm 5 \mathrm{~nm}$ excitation and $525 \pm 10 \mathrm{~nm}$ emission for 30 rounds every 30 s using a Tecan Infinite 200 Pro photometer. The result is the increase of fluorescence over time of one experiment that was run in a technical triplicate.

\section{In vitro Secretion Time Course}

Yersinia enterocolitica (MRS40) were selected for the in vitro secretion assay to compare the effector export over time. $Y$. enterocolitica were grown as stated above for the $\beta$-lactamase assay. At each indicated time point $(0,5,10,15,30,45,60$, and $120 \mathrm{~min}$ secreting; $120 \mathrm{~min}$ non-secreting) following activation, 
$2 \mathrm{ml}$ of culture samples were taken for further analysis (see secretion analysis).

\section{Growth Curve Experiment}

Yersinia enterocolitica MRS40, AD4051 ( $\Delta$ SctD), and IM41 $(\Delta \mathrm{SctW}=\mathrm{YopN})$ cultures for growth curve experiments were inoculated from overnight cultures to an $\mathrm{OD}_{600}$ of 0.12 in nonsecreting BHI medium. After incubating at $28^{\circ} \mathrm{C}$ for $1.5 \mathrm{~h}$, the culture was divided in three parts and collected $(2,400 \mathrm{~g}, 4 \mathrm{~min}$, $37^{\circ} \mathrm{C}$ ). The pellet was then resuspended in either non-secreting medium (one part) or secreting medium (two parts), both prewarmed at $37^{\circ} \mathrm{C}$, to induce the yop regulon. The cultures were incubated at $37^{\circ} \mathrm{C}$ for $2 \mathrm{~h}$, and collected again $(2,400 \mathrm{~g}, 4 \mathrm{~min}$, $37^{\circ} \mathrm{C}$ ). One previously secreting culture was resuspended in secreting medium and the second was resuspended in nonsecreting medium; the previously non-secreting culture was resuspended in fresh non-secreting medium, all pre-warmed at $37^{\circ} \mathrm{C}$. Cultures were incubated at $37^{\circ} \mathrm{C}$ for $3.5 \mathrm{~h}$. Throughout the experiment, the optical density at $600 \mathrm{~nm}$ wavelength $\left(\mathrm{OD}_{600}\right)$ of all cultures was measured every $30 \mathrm{~min}$ in a 1:3 dilution. The number of divisions per time for each culture was determined using the $\mathrm{OD}_{600}$ values for $-1.5 \mathrm{~h}$ and $0 \mathrm{~h}\left(28^{\circ} \mathrm{C}\right), 0 \mathrm{~h}$ and $2 \mathrm{~h}$ (first incubation), and $2 \mathrm{~h}$ and $4 \mathrm{~h}$ (second incubation).

\section{Secretion Analysis}

Culture samples were centrifuged $\left(20,000 \mathrm{~g}, 5 \mathrm{~min}, 4^{\circ} \mathrm{C}\right)$ and $1.8 \mathrm{ml}$ of the supernatant ( $\mathrm{SN}$ ) was collected. $\mathrm{SN}$ proteins were precipitated using trichloroacetic acid $10 \%(\mathrm{w} / \mathrm{v})$ final for $24-48 \mathrm{~h}$ at $4{ }^{\circ} \mathrm{C}$. Proteins were separated on $4-20 \%$ gradient SDS-PAGE gels (BioRad). Samples were normalized to contain the proteins secreted by $0.4 \mathrm{OD}$ units of bacteria (the equivalent of $0.4 \mathrm{ml}$ culture at an $\mathrm{OD}_{600}$ of 1 ). Secreted proteins were stained with "Instant Blue," Coomassie-based staining solution (Expedeon). Immunoblots were carried out using rabbit polyclonal primary antibodies against $Y$. enterocolitica SctP (MIPA57, 1:3000), YopE (MIPA73, 1:1000), SctA (LcrV) (MIPA220, 1:2000), or SctF (MIPA223, 1:1000), goat anti-rabbit secondary antibodies conjugated to horseradish peroxidase (Dako, 1:5000), and ECL chemiluminescent substrate (Pierce).

\section{Fluorescence Microscopy-Visualization of Growth Under Secreting and Non-secreting Conditions}

Yersinia enterocolitica AD4483 ( $\triangle$ HOPEMTasd EGFP-SctL $\Delta$ SctD) (Diepold et al., 2017) and ADTM4521 ( $\Delta$ HOPEMTasd mCherry-SctL) cultures for microscopy were inoculated from overnight cultures to an $\mathrm{OD}_{600}$ of 0.15 in secreting medium. Cultures were incubated at $28^{\circ} \mathrm{C}$ for $1.5 \mathrm{~h}$ and then shifted to $37^{\circ} \mathrm{C}$ for $2 \mathrm{~h}$. Next, $750 \mu \mathrm{l}$ of each culture were centrifuged (2,400 g, $3 \mathrm{~min})$, and resuspended in $100 \mu \mathrm{l}$ of either secreting or non-secreting medium for both strains. $2 \mu \mathrm{l}$ of resuspended culture were spotted on preheated $\left(37^{\circ} \mathrm{C}\right)$ agarose pads containing $1.5 \%(\mathrm{w} / \mathrm{v})$ low melting agarose, $\mathrm{LB}$, nalidixic acid $(35 \mu \mathrm{g} / \mathrm{ml})$, glycerol $(0.4 \% \mathrm{v} / \mathrm{v}), \mathrm{MgCl}_{2}(20 \mathrm{mM})$ and either oxalate $(20 \mathrm{mM})$ for secreting conditions, or $\mathrm{CaCl}_{2}(5 \mathrm{mM})$ for non-secreting conditions. Bright field images were taken every $5 \mathrm{~min}$ and fluorescence images were taken every $20 \mathrm{~min}$ for $2 \mathrm{~h}$ at $37^{\circ} \mathrm{C}$ with a Deltavision Spectris optical sectioning microscope (Applied Precision) using a 100x oil immersion objective (Olympus) with a numerical aperture of 1.40. The exposure time was set to $0.2 \mathrm{~s}$, with a light intensity of $32 \%$ for bright field, $587 \mathrm{~nm}$ and $485 \mathrm{~nm}$ excitation lights. Following image acquisition, images were deconvolved using softWoRx 5.5 (standard "conservative" settings). Images were further processed with ImageJ-Fiji (National Institute of Health) using a binary mask for measuring cell growth. Red and green fluorescence was manually adjusted to discriminate T3SS-positive and T3SSnegative bacteria, respectively.

\section{Fluorescence Microscopy-Quantification of Assembled T3SS Under Secreting and Non-secreting Conditions}

$\triangle$ HOPEMTasd-based Y. enterocolitica AD4085 (EGFP-SctQ) and AD4306 (EGFP-SctD) cultures for microscopy (Kudryashev et al., 2013; Diepold et al., 2015) were inoculated from an overnight culture to an $\mathrm{OD}_{600}$ of 0.12 . Cultures were incubated at $28^{\circ} \mathrm{C}$ for $1.5 \mathrm{~h}$. After incubation, cultures were shifted to $37^{\circ} \mathrm{C}$ for $3 \mathrm{~h}$. Next, $400 \mu \mathrm{l}$ of culture was centrifuged (2,400 g, $2 \mathrm{~min}$ ) and concentrated in $200 \mu \mathrm{l}$ microscopy imaging buffer $(100 \mathrm{mM}$ HEPES pH 7.2, $100 \mathrm{mM} \mathrm{NaCl}, 5 \mathrm{mM}$ ammonium sulfate, $20 \mathrm{mM}$ sodium glutamate, $10 \mathrm{mM} \mathrm{MgCl}_{2}, 5 \mathrm{mM} \mathrm{K}_{2} \mathrm{SO}_{4}, 0.5 \%$ (w/v) casamino acids) containing diaminopimelic acid $(60 \mu \mathrm{g} / \mathrm{ml})$ and $\mathrm{CaCl}_{2}(5 \mathrm{mM})$ or EGTA $(5 \mathrm{mM})$ according to the imaging conditions (non-secreting or secreting). To test for possible loss of T3SS during extended secretion, cultures were incubated under secreting or non-secreting conditions at $28^{\circ} \mathrm{C}$ for $1.5 \mathrm{~h}$, and then shifted to $37^{\circ} \mathrm{C}$ for $3 \mathrm{~h}$. For visualization, $2 \mu \mathrm{l}$ of resuspended culture where mounted on a $1.5 \%(\mathrm{w} / \mathrm{v})$ agar pad casted with the same buffer in a depression slide and visualized in a Deltavision Spectris Optical Sectioning Microscope (Applied Precision), equipped with a UApo N 100x/1.49 oil TIRF UIS2 objective (Olympus), using an Evolve EMCCD Camera (Photometrics). The sample was illuminated for $0.15 \mathrm{~s}$ with a 488 laser in a TIRF depth of 3440.0, except for the extended secretion assay, where the exposure time was $0.3 \mathrm{~s}$ under non-TIRF conditions. The micrographs where then deconvolved using softWoRx 5.5 (standard "conservative" settings) and further processed for presentation with ImageJ-Fiji. Cells were manually counted in several fields of view.

\section{Needle Staining Protocol}

MRS40-based Y. enterocolitica $\mathrm{CH} 4006\left(\mathrm{SctF}_{\mathrm{S} 5 \mathrm{C}}\right)$ and a MRS40 wild-type control were inoculated from overnight cultures to an $\mathrm{OD}_{600}$ of 0.15 in secreting medium. Cultures were incubated at $28^{\circ} \mathrm{C}$ for $1.5 \mathrm{~h}$ and then shifted to $37^{\circ} \mathrm{C}$ for $2 \mathrm{~h}$. At this point, $500 \mu \mathrm{l}$ were transferred to a $2 \mathrm{ml}$ tube and washed with minimal medium adjusted for secreting conditions. The cells were concentrated in $100 \mu \mathrm{l}$ microscopy imaging buffer containing EGTA (5 mM) and CF-633 maleimide dye (Sigma-Aldrich, USA) $(5 \mu \mathrm{M})$ for $5 \mathrm{~min}$. The cells were then collected and washed with microscopy imaging buffer containing EGTA $(5 \mathrm{mM})$ once or four times, as indicated. Images were acquired as $\mathrm{z}$ stacks of 11 images with a stacking of $0.15 \mu \mathrm{m}$. The micrographs where 
then deconvolved using softWoRx 5.5 (standard "conservative" settings) and further processed for presentation with ImageJ-Fiji.

\section{Energy Charge Determination}

Intracellular metabolites were extracted from the total cellular biomass of wildtype $\triangle$ HOPEMTasd cultures, used in this experiment for biosafety reasons, based on a sequential quenching-extraction approach. $3 \mathrm{ml}$ culture aliquots were pipetted into $9 \mathrm{ml}$ of $60 \%(\mathrm{v} / \mathrm{v})$ cold methanol $\left(-60^{\circ} \mathrm{C}\right)$. Cells were immediately pelleted by centrifugation $\left(10 \mathrm{~min},-10^{\circ} \mathrm{C}\right.$, $20,000 \mathrm{x} \mathrm{g}$ ), and the supernatant was removed. Pellets were stored at $-80^{\circ} \mathrm{C}$ until extracted. Intracellular metabolites were extracted by adding a volume equivalent to $300 \mu \mathrm{l}$ per $3 \mathrm{ml}$ of a sample at an $\mathrm{OD}_{600}$ of 1 of both extraction fluid $\{50 \%$ (v/v) methanol, 50\% (v/v) TE buffer [10 mM TRIZMA (pH 7.0), $1 \mathrm{mM}$ EDTA $\left.] ;-20^{\circ} \mathrm{C}\right\}$ and chloroform $\left(-20^{\circ} \mathrm{C}\right)$ to each cell pellet. The resulting mixture was incubated at $4^{\circ} \mathrm{C}$ for $2 \mathrm{~h}$ on a shaking device (Eppendorf shaker) and centrifuged (10 min, $\left.-10^{\circ} \mathrm{C}, 20,000 \mathrm{x} \mathrm{g}\right)$. The upper phase of the two-phase system was filtered $(0.22 \mu \mathrm{m}$, PTFE, $4 \mathrm{~mm}$ diameter, Phenomenex $)$ and stored at $-80^{\circ} \mathrm{C}$ until the polar metabolites were analyzed.

Quantification of nucleotides was performed using a LCMS/MS. The chromatographic separation was performed on an Agilent Infinity II 1290 HPLC system using a SeQuant ZIC-HILIC column $(150 \times 2.1 \mathrm{~mm} ; 3.5 \mu \mathrm{m}, 100 \AA$, Merck, Germany) equipped with a $20 \times 2.1 \mathrm{~mm}$ guard column of similar specificity (Merck, Germany) at a constant flow rate of 0.4 $\mathrm{ml} / \mathrm{min}$ with mobile phase A being $20 \mathrm{mM}$ ammonium acetate (Sigma-Aldrich, USA) adjusted to $\mathrm{pH} 9.2$ with ammonium hydroxide (Honeywell, USA) and phase B being acetonitrile (Honeywell, USA).

The injection volume was $3 \mu \mathrm{l}$. The mobile phase profile consisted of the following steps and linear gradients: $0-1 \mathrm{~min}$ from $20 \% \mathrm{~B}$ to $25 \% \mathrm{~B} ; 1-4 \mathrm{~min}$ from 25 to $35 \% \mathrm{~B} ; 4-5 \mathrm{~min}$ from 35 to $80 \% \mathrm{~B} ; 5-6 \mathrm{~min}$ constant at $80 \% \mathrm{~B} ; 6-7 \mathrm{~min}$ from

\section{REFERENCES}

Akeda, Y., and Galán, J. E. (2005). Chaperone release and unfolding of substrates in type III secretion. Nature 437, 911-915. doi: 10.1038/nature03992

Armentrout, E. I., and Rietsch, A. (2016). The type III secretion translocation pore senses host cell contact. PLOS Pathog. 12:e1005530. doi: 10.1371/journal.ppat.1005530

Avican, K., Fahlgren, A., Huss, M., Heroven, A. K., Beckstette, M., Dersch, P., et al. (2015). Reprogramming of yersinia from virulent to persistent mode revealed by complex in vivo RNA-seq analysis. PLoS Pathog. 11:e1004600. doi: 10.1371 /journal.ppat.1004600

Behnsen, J., Jellbauer, S., Wong, C. P., Edwards, R. A., George, M. D., Ouyang, W., et al. (2014). The cytokine IL-22 promotes pathogen colonization by suppressing related commensal bacteria. Immunity 40, 262-273. doi: 10.1016/j.immuni.2014. 01.003

Böhme, K., Steinmann, R., Kortmann, J., Seekircher, S., Heroven, A. K., Berger, E., et al. (2012). Concerted actions of a thermo-labile regulator and a unique intergenic RNA thermosensor control Yersinia virulence. PLoS Pathog. 8:e1002518. doi: 10.1371/journal.ppat.1002518

Boland, A., Sory, M.-P., Iriarte, M., Kerbourch, C., Wattiau, P., and Cornelis, G. R. (1996). Status of YopM and YopN in the yersinia yop virulon: YopM of Y.enterocolitica is internalized inside the cytosol of PU5-1.8
80 to $20 \%$ B; $7-8$ min constant at $20 \%$ B. An Agilent 6495 ion funnel mass spectrometer was used in negative mode with an electrospray ionization source and the following conditions: ESI spray voltage $3,500 \mathrm{~V}$, sheath gas $350^{\circ} \mathrm{C}$ at $11 \mathrm{l} / \mathrm{min}$, nebulizer pressure $20 \mathrm{psig}$ and drying gas $225^{\circ} \mathrm{C}$ at $14 \mathrm{l} / \mathrm{min}$. Compounds were identified based on their exact mass and retention time compared to standards. Extracted ion chromatograms of the [M$\mathrm{H}$ ]- forms were integrated using MassHunter software (Agilent, Santa Clara, CA, USA). Absolute concentrations were calculated based on an external calibration curve.

\section{DATA AVAILABILITY}

All datasets generated for this study are included in the manuscript and/or the Supplementary Files.

\section{AUTHOR CONTRIBUTIONS}

BM-D and $\mathrm{AD}$ conceived, designed experiments, and wrote the paper. BM-D, CH, SW, DC, NP, and AD performed the experiments. BM-D, $\mathrm{CH}, \mathrm{SW}, \mathrm{NP}$, and $\mathrm{AD}$ analyzed the data.

\section{ACKNOWLEDGMENTS}

This work was supported by the Max Planck Society. Nucleotide analysis was performed by the Core Facility for Metabolomics and Small Molecules of the Max Planck Institute for Terrestrial Microbiology. We thank Kai Thormann, University of Gießen, for support with the visualization of needles.

\section{SUPPLEMENTARY MATERIAL}

The Supplementary Material for this article can be found online at: https://www.frontiersin.org/articles/10.3389/fmicb. 2019.02128/full\#supplementary-material macrophages by the YopB, D, N delivery apparatus. EMBO J. 15, 5191-5201. doi: 10.1002/j.1460-2075.1996.tb00904.x

Brubaker, R. R. (2005). Influence of $\mathrm{Na}(+)$, dicarboxylic amino acids, and $\mathrm{pH}$ in modulating the low-calcium response of Yersinia pestis. Infect. Immun. 73, 4743-4752. doi: 10.1128/IAI.73.8.4743-4752.2005

Büttner, D. (2012). Protein export according to schedule: architecture, assembly, and regulation of type III secretion systems from plant- and animal-pathogenic bacteria. Microbiol. Mol. Biol. Rev. 76, 262-310. doi: 10.1128/MMBR.05017-11

Charpentier, X., and Oswald, E. (2004). Identification of the secretion and translocation domain of the enteropathogenic and enterohemorrhagic Escherichia coli effector Cif, using TEM-1 beta-lactamase as a new fluorescence-based reporter. J. Bacteriol. 186, 5486-5495. doi: 10.1128/JB.186.16.5486-5495.2004

Cisz, M., Lee, P. C., and Rietsch, A. (2008). ExoS controls the cell contactmediated switch to effector secretion in Pseudomonas aeruginosa. J. Bacteriol. 190, 2726-2738. doi: 10.1128/JB.01553-07

Cornelis, G., Vanooteghem, J., and Sluiters, C. (1987). Transcription of the yop regulon from $Y$. enterocolitica requires trans acting pYV and chromosomal genes. Microb. Pathog. 2, 367-379. doi: 10.1016/0882-4010(87)90078-7

Cornelis, G. R. (2002). Yersinia type III secretion: send in the effectors. J. Cell Biol. 158, 401-408. doi: 10.1083/jcb.200205077

Cornelis, G. R. (2006). The type III secretion injectisome. Nat. Rev. Microbiol. 4, 811-825. doi: 10.1038/nrmicro1526 
Cornelis, G. R., Biot, T., Lambert de Rouvroit, C., Michiels, T., Mulder, B., Sluiters, C., et al. (1989). The Yersinia yop regulon. Mol. Microbiol. 3, 1455-1459. doi: 10.1111/j.1365-2958.1989.tb00129.x

Davis, A. J., and Mecsas, J. (2006). Mutations in the Yersinia pseudotuberculosis type III secretion system needle protein, YscF, that specifically abrogate effector translocation into host cells. J. Bacteriol. 189, 83-97. doi: 10.1128/JB.01396-06

Deng, W., Marshall, N. C., Rowland, J. L., McCoy, J. M., Worrall, L. J., Santos, A. S., et al. (2017). Assembly, structure, function and regulation of type III secretion systems. Nat. Rev. Microbiol. 15, 323-337. doi: 10.1038/nrmicro.2017.20

Dewoody, R. S., Merritt, P. M., and Marketon, M. M. (2013). Regulation of the Yersinia type III secretion system: traffic control. Front. Cell. Infect. Microbiol. 3:4. doi: 10.3389/fcimb.2013.00004

Diard, M., Garcia, V., Maier, L., Remus-Emsermann, M. N. P., Regoes, R. R., Ackermann, M., et al. (2013). Stabilization of cooperative virulence by the expression of an avirulent phenotype. Nature 494, 353-356. doi: $10.1038 /$ nature 11913

Diepold, A., Amstutz, M., Abel, S., Sorg, I., Jenal, U., and Cornelis, G. R. (2010). Deciphering the assembly of the Yersinia type III secretion injectisome. EMBO J. 29, 1928-1940. doi: 10.1038/emboj.2010.84

Diepold, A., Kudryashev, M., Delalez, N. J., Berry, R. M., and Armitage, J. P. (2015). Composition, formation, and regulation of the cytosolic c-ring, a dynamic component of the type III secretion injectisome. PLOS Biol. 13:e1002039. doi: 10.1371/journal.pbio.1002039

Diepold, A., Sezgin, E., Huseyin, M., Mortimer, T., Eggeling, C., and Armitage, J. P. (2017). A dynamic and adaptive network of cytosolic interactions governs protein export by the T3SS injectisome. Nat. Commun. 8:15940. doi: $10.1038 /$ ncomms 15940

Diepold, A., and Wagner, S. (2014). Assembly of the bacterial type III secretion machinery. FEMS Microbiol. Rev. 38, 802-822. doi: 10.1111/1574-6976.12061

Diepold, A., Wiesand, U., and Cornelis, G. R. (2011). The assembly of the export apparatus (YscR,S,T,U,V) of the Yersinia type III secretion apparatus occurs independently of other structural components and involves the formation of an YscV oligomer. Mol. Microbiol. 82, 502-514. doi: 10.1111/j.1365-2958.2011.07830.x

Enninga, J., Mounier, J., Sansonetti, P., Tran Van Nhieu, G., and Van Nhieu, G. T. (2005). Secretion of type III effectors into host cells in real time. Nat. Methods 2, 959-965. doi: 10.1038/nmeth804

Enninga, J., and Rosenshine, I. (2009). Imaging the assembly, structure and activity of type III secretion systems. Cell. Microbiol. 11, 1462-1470. doi: 10.1111/j.1462-5822.2009.01360.x

Fowler, J. M., and Brubaker, R. R. (1994). Physiological basis of the low calcium response in Yersinia pestis. Infect. Immun. 62, 5234-5241.

Fowler, J. M., Wulff, C. R., Straley, S., and Brubaker, R. R. (2009). Growth of calcium-blind mutants of Yersinia pestis at $37 \mathrm{C}$ in permissive $\mathrm{Ca} 2+$-deficient environments. Microbiology 155, 2509-2521. doi: 10.1099/mic.0.028852-0

Galán, J. E. (2009). Common themes in the design and function of bacterial effectors. Cell Host Microbe 5, 571-579. doi: 10.1016/j.chom.2009.04.008

Grosdent, N., Maridonneau-Parini, I., Sory, M.-P., and Cornelis, G. R. (2002). Role of yops and adhesins in resistance of yersinia enterocolitica to phagocytosis. Infect. Immun. 70, 4165-4176. doi: 10.1128/IAI.70.8.4165-4176.2002

Håkansson, S., Schesser, K., Persson, C., Galyov, E. E., Rosqvist, R., Hombl,é, F., et al. (1996). The YopB protein of Yersinia pseudotuberculosis is essential for the translocation of Yop effector proteins across the target cell plasma membrane and displays a contact-dependent membrane disrupting activity. EMBO J. 15, 5812-5823. doi: 10.1002/j.1460-2075.1996.tb00968.x

Heroven, A. K., and Dersch, P. (2014). Coregulation of host-adapted metabolism and virulence by pathogenic yersiniae. Front. Cell. Infect. Microbiol. 4:146. doi: $10.3389 /$ fcimb. 2014.00146

Hoe, N., and Goguen, J. D. (1993). Temperature sensing in Yersinia pestis: translation of the LcrF activator protein is thermally regulated. J. Bacteriol. 175, 7901-7909. doi: 10.1128/jb.175.24.7901-7909.1993

Hueck, C. J. (1998). Type III protein secretion systems in bacterial pathogens of animals and plants. Microbiol. Mol. Biol. Rev. 62, 379-433.

Kaniga, K., Delor, I., and Cornelis, G. R. (1991). A wide-hostrange suicide vector for improving reverse genetics in Gramnegative bacteria: inactivation of the blaA gene of Yersinia enterocolitica. Gene 109, 137-141. doi: 10.1016/0378-1119(91) 90599-7
Kenjale, R., Wilson, J., Zenk, S., Saurya, S., Picking, W. L., and Blocker, A. J. (2005). The needle component of the type III secreton of Shigella regulates the activity of the secretion apparatus. J. Biol. Chem. 280, 42929-42937. doi: 10.1074/jbc.M508377200

Knodler, L. A., Vallance, B. A., Celli, J., Winfree, S., Hansen, B., Montero, M., et al. (2010). Dissemination of invasive Salmonella via bacterial-induced extrusion of mucosal epithelia. Proc. Natl. Acad. Sci. U.S.A. 107, 17733-17738. doi: 10.1073/pnas.1006098107

Kudryashev, M., Diepold, A., Amstutz, M., Armitage, J. P., Stahlberg, H., and Cornelis, G. R. (2015). Yersinia enterocolitica type III secretion injectisomes form regularly spaced clusters, which incorporate new machines upon activation. Mol. Microbiol. 95, 875-884. doi: 10.1111/mmi.12908

Kudryashev, M., Stenta, M., Schmelz, S., Amstutz, M., Wiesand, U., CastañoDíez, D., et al. (2013). In situ structural analysis of the Yersinia enterocolitica injectisome. Elife 2:e00792. doi: 10.7554/eLife.00792

Kuhlen, L., Abrusci, P., Johnson, S., Gault, J., Deme, J., Caesar, J., et al. (2018). Structure of the core of the type III secretion system export apparatus. Nat. Struct. Mol. Biol. 25, 583-590. doi: 10.1038/s41594-018-0086-9

Kupferberg, L. L., and Higuchi, K. (1958). Role of calcium ions in the stimulation of growth of virulent strains of Pasteurella pestis. J. Bacteriol. 76, 120-121.

Lambert de Rouvroit, C., Sluiters, C., and Cornelis, G. R. (1992). Role of the transcriptional activator, VirF, and temperature in the expression of the pYV plasmid genes of Yersinia enterocolitica. Mol. Microbiol. 6, 395-409. doi: 10.1111/j.1365-2958.1992.tb01483.x

Lara-Tejero, M., Kato, J., Wagner, S., Liu, X., and Galán, J. E. (2011). A sorting platform determines the order of protein secretion in bacterial type III systems. Science 331, 1188-1191. doi: 10.1126/science.1201476

Marketon, M. M., DePaolo, R. W., DeBord, K. L., Jabri, B., and Schneewind, O. (2005). Plague bacteria target immune cells during infection. Science 309, 1739-1741. doi: 10.1126/science. 1114580

Mehigh, R. J., Sample, A. K., and Brubaker, R. R. (1989). Expression of the low calcium response in Yersinia pestis. Microb. Pathog. 6, 203-217. doi: 10.1016/0882-4010(89)90070-3

Mills, E., Baruch, K., Charpentier, X., Kobi, S., and Rosenshine, I. (2008). Real-time analysis of effector translocation by the type III secretion system of enteropathogenic Escherichia coli. Cell Host Microbe 3, 104-113. doi: 10.1016/j.chom.2007.11.007

Mueller, C. A., Broz, P., Müller, S. A., Ringler, P., Erne-Brand, F., Sorg, I., et al. (2005). The V-antigen of Yersinia forms a distinct structure at the tip of injectisome needles. Science 310, 674-676. doi: 10.1126/science.1118476

Müller, A. J., Hoffmann, C., Galle, M., Van Den Broeke, A., Heikenwalder, M., Falter, L., et al. (2009). The, S. typhimurium effector sope induces caspase-1 activation in stromal cells to initiate gut inflammation. Cell Host Microbe 6, 125-136. doi: 10.1016/j.chom.2009.07.007

Nauth, T., Huschka, F., Schweizer, M., Bosse, J. B., Diepold, A., Failla, A. V., et al. (2018). Visualization of translocons in Yersinia type III protein secretion machines during host cell infection. PLOS Pathog. 14:e1007527. doi: 10.1371/journal.ppat.1007527

Navarro, L., Alto, N. M., and Dixon, J. E. (2005). Functions of the Yersinia effector proteins in inhibiting host immune responses. Curr. Opin. Microbiol. 8, 21-27. doi: 10.1016/j.mib.2004.12.014

Park, D., Lara-Tejero, M., Waxham, M. N., Li, W., Hu, B., Galán, J. E., et al. (2018) Visualization of the type III secretion mediated Salmonella-host cell interface using cryo-electron tomography. Elife 7:e39514. doi: 10.7554/eLife.39514

Pha, K. (2016). Yersinia type III effectors perturb host innate immune responses. World, J. Biol. Chem. 7:1. doi: 10.4331/wjbc.v7.i1.1

Philip, N. H., Zwack, E. E., and Brodsky, I. E. (2016). Activation and evasion of inflammasomes by yersinia. Curr. Top. Microbiol. Immunol. 397, 69-90. doi: 10.1007/978-3-319-41171-2_4

Portaliou, A. G., Tsolis, K. C., Loos, M. S., Zorzini, V., and Economou, A. (2016). Type III secretion: building and operating a remarkable nanomachine. Trends Biochem. Sci. 41, 175-189 doi: 10.1016/j.tibs.2015.09.005

Ramos-Morales, F. (2012). Impact of Salmonella enterica type III secretion system effectors on the eukaryotic host cell. ISRN Cell Biol. 2012, 1-36. doi: $10.5402 / 2012 / 787934$

Rietsch, A., and Mekalanos, J. J. (2006). Metabolic regulation of type III secretion gene expression in Pseudomonas aeruginosa. Mol. Microbiol. 59, 807-820. doi: $10.1111 / \mathrm{j} .1365-2958.2005 .04990 . \mathrm{x}$ 
Roehrich, A. D., Guillossou, E., Blocker, A. J., and Martinez-Argudo, I. (2013). Shigella IpaD has a dual role: signal transduction from the type III secretion system needle tip and intracellular secretion regulation. Mol. Microbiol. 87, 690-706. doi: 10.1111/mmi.12124

Rundell, E. A., McKeithen-Mead, S. A., and Kazmierczak, B. I. (2016). Rampant cheating by pathogens? PLOS Pathog. 12:e1005792. doi: 10.1371/journal.ppat.1005792

Sánchez-Romero, M. A., and Casadesús, J. (2018). Contribution of SPI-1 bistability to Salmonella enterica cooperative virulence: insights from single cell analysis. Sci. Rep. 8:14875. doi: 10.1038/s41598-018-33137-z

Schlumberger, M. C., Müller, A., Ehrbar, K., Winnen, B., Duss, I., Stecher, B., et al. (2005). Real-time imaging of type III secretion: salmonella SipA injection into host cells. Proc. Natl. Acad. Sci. U.S.A. 102, 12548-12553. doi: 10.1073/pnas.0503407102

Shaulov, L., Gershberg, J., Deng, W., Finlay, B. B., and Sal-Man, N. (2017). The ruler protein escp of the enteropathogenic Escherichia coli type III secretion system is involved in calcium sensing and secretion hierarchy regulation by interacting with the gatekeeper protein SepL. MBio 8:e01733-e01716. doi: $10.1128 / \mathrm{mBio} .01733-16$

Skurnik, M., Bölin, I., Heikkinen, H., Piha, S., and Wolf-Watz, H. (1984). Virulence plasmid-associated autoagglutination in Yersinia spp. J. Bacteriol. 158, 1033-1036.

Sory, M.-P., Boland, A., Lambermont, I., and Cornelis, G. R. (1995). Identification of the YopE and YopH domains required for secretion and internalization into the cytosol of macrophages, using the cyaA gene fusion approach. Proc. Natl. Acad. Sci. U.S.A. 92, 11998-12002. doi: 10.1073/pnas.92.26.11998

Stecher, B., Robbiani, R., Walker, A. W., Westendorf, A. M., Barthel, M., Kremer, M., et al. (2007). Salmonella enterica serovar typhimurium exploits inflammation to compete with the intestinal microbiota. PLoS Biol. 5, 2177-2189. doi: 10.1371/journal.pbio.0050244

Sturm, A., Heinemann, M., Arnoldini, M., Benecke, A., Ackermann, M., Benz, M., et al. (2011). The cost of virulence: retarded growth of Salmonella Typhimurium cells expressing type III secretion system 1. PLoS Pathog. 7:e1002143. doi: 10.1371/journal.ppat.1002143
Torruellas, J., Jackson, M. W., Pennock, J. W., and Plano, G. V. (2005). The Yersinia pestis type III secretion needle plays a role in the regulation of Yop secretion. Mol. Microbiol. 57, 1719-1733. doi: 10.1111/j.1365-2958.2005.04790.x

Veenendaal, A. K. J., Hodgkinson, J., Schwarzer, L., Stabat, D., Zenk, S., and Blocker, A. J. (2007). The type III secretion system needle tip complex mediates host cell sensing and translocon insertion. Mol. Microbiol. 63, 1719-1730. doi: 10.1111/j.1365-2958.2007.05620.x

Wang, H., Avican, K., Fahlgren, A., Erttmann, S. F., Nuss, A. M., Dersch, P., et al. (2016). Increased plasmid copy number is essential for Yersinia T3SS function and virulence. Science 353, 492-495. doi: 10.1126/science.aaf7501

Weigel, W. A., and Dersch, P. (2018). Phenotypic heterogeneity: a bacterial virulence strategy. Microbes Infect. 20, 570-577. doi: 10.1016/j.micinf.2018.01.008

Wiley, D. J., Rosqvist, R., and Schesser, K. (2007). Induction of the yersinia type 3 secretion system as an all-or-none phenomenon. J. Mol. Biol. 373, 27-37. doi: 10.1016/j.jmb.2007.07.077

Wilharm, G., and Heider, C. (2014). Interrelationship between type three secretion system and metabolism in pathogenic bacteria. Front. Cell. Infect. Microbiol. 4:150. doi: 10.3389/fcimb.2014. 00150

Yother, J., and Goguen, J. D. (1985). Isolation and characterization of Ca2+-blind mutants of Yersinia pestis. J. Bacteriol. 164, 704-711.

Conflict of Interest Statement: The authors declare that the research was conducted in the absence of any commercial or financial relationships that could be construed as a potential conflict of interest.

Copyright (c) 2019 Milne-Davies, Helbig, Wimmi, Cheng, Paczia and Diepold. This is an open-access article distributed under the terms of the Creative Commons Attribution License (CC BY). The use, distribution or reproduction in other forums is permitted, provided the original author(s) and the copyright owner(s) are credited and that the original publication in this journal is cited, in accordance with accepted academic practice. No use, distribution or reproduction is permitted which does not comply with these terms. 